\title{
AN ANALYSIS OF DONAL J.TRUMPS REMARKS "MY FELLOW AMERICANS" USING INTERPERSONAL METAFUNCTION
}

\author{
Mayang Sari' ${ }^{1}$, Dian Meta Arani' ${ }^{2}$, Iman Santoso \\ ${ }^{1}$ IKIP Siliwangi \\ ${ }^{2}$ IKIP Siliwangi \\ ${ }^{3}$ IKIP Siliwangi \\ 1'Kumaymay26@yahoo.com, 2DianmetaNR@gmail.com, 3imansantoso515@gmail.com
}

\begin{abstract}
The aims of this reasearch is analyzing President Donal J.Trump statement in weekly address on www.whitehouse.gov entitle "My fellow american" based on systemic functional grammar. The writers focused on interpersonal metafunction which consist of mood and speech functions. The method in this research used qualitative analysis method. The data were analyzed using mood structure analysis by M.A.K Haliday. The text entitled My Fellow American the statement by President Donal J.Trump Remarks is categorized into the text which uses declarative mood type the most $(69,2 \%)$ which indicates the position o the speaker provider of information and the listeners as the recepeint of information. The clauses in the text are said by temporal deicticity or finite tense the most $(89 \%)$, while the modality deicticity only appears a little (5\%) which indicates that the speaker has no right to persuade the listeners because the genre of the text is narrative which functions only to telling the listeners. There are only two speech functions found in the transcipt of President Donal J.Trump are statment and question. Statement as mostly appeared in the text which reaches precentage $75 \%$ whereas question only reaches percentage $25 \%$. So it can be concluded that speech function used in the transcipt is statement with function to give information.
\end{abstract}

Keywords:Interpersonal Metafunction, Mood and Speech Function.

\section{INTRODUCTION}

According to (Eggins \& Slade, 1997) in Efiyatul Ngazizah "Every aspect of humans life must be fulfilled by a language in undergoing their daily routines, for instance, sign, symbol, or the oral speech, etc; those belong to a language. Public speaking is a communicating process between the speaker to give information to the audience". basicly the speakers boil down to who is saying what to whom using what the medium with what effect.

According (Michael A. K. Halliday \& Matthiessen, 2014) the context of situation is arraged in three categories, there are field, tenor and mode. Halliday also analyze the language into three broad metafunction they are Interpersonal Metafunctions, Experiential Metafunctions, and Textual Metafunctions. In this research the writers focus on the Interpersonal Metafunction. Interpersonal Metafunction that users of language establish, negotiate and assume their position in social relationships, and it is cornerned with clauses as exchange (Michael Alexander Kirkwood Halliday \& Matthiessen, 2004). Following Systematic Functional Grammar (SFL), in this research on a tentative interpersonal metafunction analysis of Donal J.Trump Weekly 
address from the perspective of Interpersonal Metafunctions, while aims to help readers or listeners understand and evaluate the speech regarding its suitability to provide some guidance for readers or listeners to make better speech.

SFG (Systemic Functional Grammar) is a study meaning construction through systems of lexico grammatical choices that serve functions within social and cultural context. Functional grammar is a widely used systemic grammar functional. Functional grammar has two kinds of meanings, i.e. ideational and interpersonal meanings. (Michael Alexander Kirkwood Halliday \& Matthiessen, 2004) states that the nature of language is a semiotic system. The semiotic system has three meta-functions, there are ideational function, interpersonal function, and textual function. According Halliday, the ideational function is the employment of language to reflect the speakers or writers experience that is their wordls of reality of imagination.

This reasearch focused on th kind of clause as an exchange, so interpersonal meaning of clause is used. Interpersonal meaning consists of mood and residu. From the data and the analysis of statement Donal J.Trump Weekly Address. The text use mood structure with from of subject and finite. The residu stucture in this analysis shows that not each clausesd used the from of predicate, complement, and adjunct. Most of all clauses in the text use the pattern of giving information of the statement.

The mood stucture in SFG analysis approaches has two types of mood. The two types of mood are indicative mood and imperative mood. In this case, this research focused on the the types of mood from indicative mood. Indicative mood is divided into two namely the declarative mood and interrogative mood. The mood is built by two element of the subject and finite. (Gerot \& Wignel, 1994) states that Mood in English is realized by the position in the clause of the subject and finite. They argue that each type of mood can be analyzed in clauses of the subject and finite. Both the element build declarative and interrogative mood. Thus the constituent that constructs the subject has a diversity of constituents. Finite that builds the mood can simply show a clauses is constituens and gives an indication of the importance of the constituents raised.

In this research the writers focused on the type of mood in the theme ideational. Thus in the framework, the writers used some theories are M. Ak Haliday and Linda Gerot and Peter Wignell (1944) as supporting theories. According (Michael Alexander Kirkwood Halliday \& Matthiessen, 2004) that "Subject is an element which the assertion is climed to have validity, that the functions to realize the thing by reference to which the proposition can be affirmed or denied. It provides the person or thing that is responsible for the success of the proposal and for functioning of the clause as an interactive event". Haliday's statement of finite, finite is divided in two categories namely tense and modality. Primary tense can be past, present, and future.

Systemic funcional linguistic (SFL) is a study of language that views language as two characteristics, systemic and functional. It is systemic because SFL uses theory of meaning as a choice, by which a language or any other semiotic system is interpered as networks of intelocking options. In the systemic functional language, there are fundamental components of meaning is metafunction. According to (Michael A. K. Halliday \& Matthiessen, 2014) that the functional components are ideational meaning, interprsonal meaning, and textual meaning. The ideational meaning is the meaning function to represent patterns of expriences inconstrucing mental images of the reality that takes place around them and inside them. The interpersonal meaning is concerned with the interaction between speakers or writer and listener or readers. The function is to enabling of exchanging roles in rhetorical interaction are statements, 
questions, offers and commands. The textual meaning is concerned with the organization of the text in which the experiental, logical and interpersonal are bound together into a coherent. On the other words, the textual menings is about the message for example foregrounding/salience; types of cohesion (Eggins \& Slade, 1997). The interpersonal functions play the role of setting up and maintaining social relations and indicate the role of the participants in the communications (Michael Alexander Kirkwood Halliday \& Matthiessen, 2004).

Language involves an interaction where we initiate or respond to the act of giving or demanding for good and services or information. The function as ome exvhange and the principle grammatical system here is mood network (Michael Alexander Kirkwood Halliday \& Matthiessen, 2004). In which is a choice between imperative and indicative. If we chose indicative it means that a choice between declarative and interrogative the choices are realised by manipulating the mood element.

Language serve a range functions, it is usually adjusted the speech to suit the social context of speech. Divided speech funtion into seven classifications. They are the referential, the expressive or emotive, directive or conative, phatic (contact), contexual, topic, the expressive to addresser and the directive to addressee. Contextual function often serves to give formal notice of a set of conditions which certain right and impose certain obligations on the participants in the speech event.

In this research we focusing on the mood system. Thus, we are talking about the clause as exchange. Making an utterance is an interactive event inherently involving between a speaker or writer and listener or reader (addresse). A speaker in uttering selects a speech role for her or himself and simulationeously and thereby allocates a speech role to the addressee. The mood carries the interpersonal functions of the clause and consist of Subject + Finite. The subject is realised by a nominal group that the speaker gives responsibilty to for the validy of the clause., while the finite is realised by the frist of the verbal group. The rest of verbal group is Predicator, which forms part of the Residue. A clause thus consistsof the Mood + Residue. The mood element can be identified in Mood tags (pedagogically, question tags).

For example:

he fought to defend the forgotten men

\begin{tabular}{ll|lll}
\hline $\mathrm{He}$ & Fought & to defend & the forgotten men \\
\hline Subject & Finite & Predicator & Adjunct & Complement \\
\hline MOOD: Indicative & RESIDUE & \\
\hline
\end{tabular}

Does it sound familiar?

\begin{tabular}{llrll}
\hline Does & It & \multicolumn{2}{l}{ Sound } & Familiar \\
\hline Mood Tag & Subject & Finite & Predicator & Complement \\
\hline \multicolumn{4}{l}{ MOOD: Subjunctive } & RESIDUE \\
\hline
\end{tabular}

\section{METHOD}

This research used qualitative analysis carries on a tentative interpersonal metafunction analysis statement of Donal J.Trump's in Weekly Address "My Fellow American". The writers get the transcipt of statement in www.whitehouse.gov and analyzed based on Halliday and Parrot \& 
Wignell Theory. The writers describes the interpretation of interpersonal meaning and speech acts function.

\section{RESULTS AND DISCUSSION}

\section{Result}

Finite its means that finite is always preceded by subject, it indicates that those are statement speech functions realized in terms of declarative moods. Bellow are the analysis speech act of Donal J.Trump in white house weekly remaks base on three catgories of mood stucture.

\section{Discussion}

There are 26 clauses as exchange found in the statement of President Donal J.Trump "My Fellow American". It can be explain below:

\section{Interpersonal Meaning}

\section{Type of mood}

There are two types of mood, namely indicative mood and imperative mood. In the indicative mood have two types they are declarative and interrogative.

\section{Indicative mood}

Indicative mood is realised by the features subject + finite. The order of the subject and finite realises declarative and interrogative.

\section{Declarative mood}

Is expressed by statement. The clause which is included into declarative mood is when the position of the subject is before the finite. This is the data of the analysis below:

Data : This week, I traveled to Nasville

\begin{tabular}{|c|c|c|c|c|}
\hline This week & I & \multicolumn{2}{|c|}{ Traveled } & To Nashville \\
\hline Adjunct & Subject & Finite & Predicator & Adjunct \\
\hline \multicolumn{4}{|c|}{ MOOD: Indicative (Declarative) } & RESIDUE \\
\hline
\end{tabular}

Data : He fought to defend the forgotten men

\begin{tabular}{|c|c|c|c|c|}
\hline $\mathrm{He}$ & Fol & & to defend & the forgotten me \\
\hline Subject & Finite & Predicator & Adjunct & Complement \\
\hline
\end{tabular}

Data : The memory of his leadership lives on in our people

\begin{tabular}{|c|c|c|c|}
\hline The memory of his leadership & \multicolumn{2}{|c|}{ lives on } & in our people \\
\hline Subject & Finite & Predicator & Adjunct \\
\hline \multicolumn{3}{|c|}{ MOOD: Indicative (Declarative) } & RESIDUE \\
\hline
\end{tabular}

Data : His spirit points us to a better future 


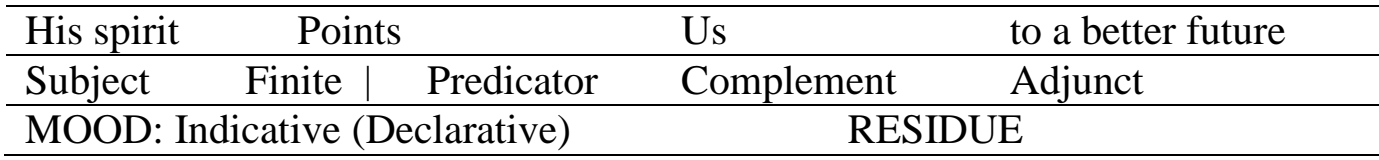

Data: This week, the old plant was filled once again with thousands of workers and engineers.

\begin{tabular}{|c|c|c|c|c|c|}
\hline This week & The old plant & \multicolumn{2}{|c|}{ was filled } & once again & $\begin{array}{l}\text { with thousand of } \\
\text { worker and engineers }\end{array}$ \\
\hline \multirow[t]{2}{*}{ Adjunct } & $\begin{array}{l}\text { Passive } \\
\text { Subject }\end{array}$ & Finite | & $\begin{array}{l}\text { Passive } \\
\text { Predicator }\end{array}$ & Adjunct & Complement \\
\hline & \multicolumn{3}{|c|}{ MOOD: Indicative (Declarative) } & \multicolumn{2}{|c|}{ RESIDUE } \\
\hline
\end{tabular}

Data: I was there to share the good news for the American auto industry.

\begin{tabular}{|c|c|c|c|c|c|}
\hline I & Was & & There & to share the good news & $\begin{array}{l}\text { for the American auto } \\
\text { industry }\end{array}$ \\
\hline Subject & Finite & To be & Adjunct & Adjunct & Complement \\
\hline \multicolumn{4}{|c|}{ MOOD: Indicative (Declarative) } & RESIDUE & \\
\hline
\end{tabular}

Data : I mean threatening

\begin{tabular}{lll}
\hline I & Mean & threatening \\
\hline Subject $\quad$ Finite | Predicator & Adjunct \\
\hline MOOD: Indicative (Declarative) & RESIDUE \\
\hline
\end{tabular}

Data : The first two job reports of my administration

\begin{tabular}{llll}
\hline The first two job & \multicolumn{2}{c}{ Reports } & of my administration \\
\hline Subject & Finite & Predicator & Complement \\
\hline MOOD: Indicative (Declarative) & RESIDUE \\
\hline
\end{tabular}

Data : We need a new economic model

\begin{tabular}{ll|lll}
\hline We & \multicolumn{2}{c}{ Need } & a new & economic model \\
\hline Subject & Finite & Predicator & Adjunct & Complement \\
\hline \multicolumn{2}{c}{ MOOD: Declarative } & RESIDUE & \\
\hline
\end{tabular}

Data : we will lower the burden on American Business

\begin{tabular}{llll}
\hline We & Will & lower the burden & on American business \\
\hline Subject & Finite:Modals & Adjunct & Complement \\
\hline MOOD: Indicative & \multicolumn{2}{c}{ RESIDUE } \\
\hline
\end{tabular}

Data : They must hire and grow America and American jobs. 


\begin{tabular}{llll}
\hline They & Must & hire and grow & America and American jobs \\
\hline Subject & Finite: Modals & Adjunct & Complement \\
\hline \multicolumn{2}{c}{ MOOD: Subjunctive } & \multicolumn{2}{c}{ RESIDUE } \\
\hline
\end{tabular}

Data : They called her Rosie the Riveter.

\begin{tabular}{lllll}
\hline They & \multicolumn{2}{c}{ Called } & Her & Rosie the Riveter \\
\hline Subject & Finite & Predicator & Complement & Adjunct \\
\hline \multicolumn{2}{c}{ MOOD: Indicative } & \multicolumn{2}{c}{ RESIDUE } \\
\hline
\end{tabular}

Data : She answered the call.

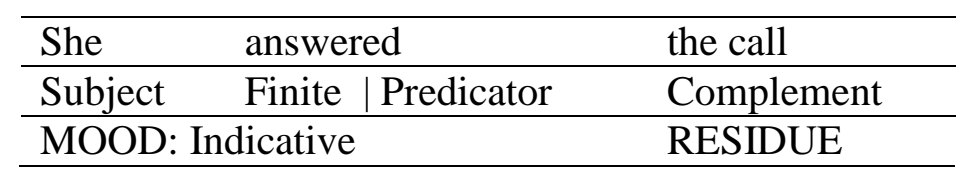

Data : Rosie was famous for her toughness and her strength

\begin{tabular}{lllll}
\hline Rosie & \multicolumn{2}{c}{ Was } & Famous & For her toughness and her strength \\
\hline Subject & Finite & To be & Head & Complement \\
\hline \multicolumn{2}{l}{ MOOD: Indicative (Declarative) } & \multicolumn{2}{c}{ RESIDUE } \\
\hline
\end{tabular}

Data : We can do it.

\begin{tabular}{llll}
\hline We & \multicolumn{2}{c}{ Can } & do it \\
\hline Subject & Finite & Modals & Complement \\
\hline MOOD: Indicative (Declarative) & RESIDUE \\
\hline
\end{tabular}

Data: I have no doubt that we can do it.

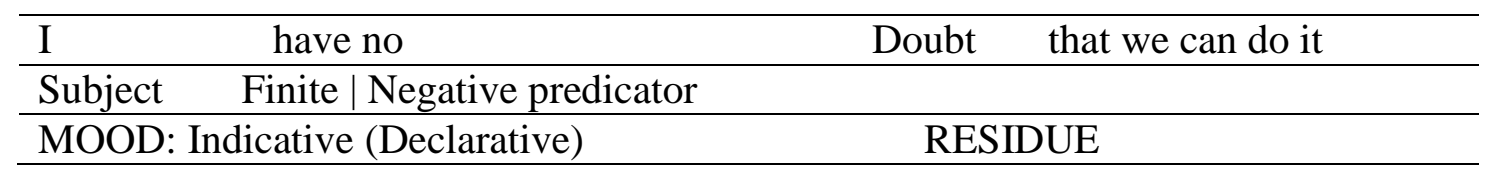

From the mood structure above, it can be found that there are two clauses in a sentence. The interlocuter is the speaker and the listeners is the speker as the provider of infomation and the recipient of the information. The speakers provide the information to the listeners about thr economy of Americans.

\section{Interrogative Mood}

Interrogative mood is expressed by question. The clause which is included into interrogative mood is when the position of the subject after the finite .

Data : Does it sound familiar?

\begin{tabular}{llll}
\hline Does & It & Sound & familiar \\
\hline Finite & Subject & Predicator & Complement \\
\hline & MOOD: Interrogative & RESIDUE \\
\hline
\end{tabular}


From the mood structure above, it can be found that are only one clauses sentence. The clause is a question. It can be identified by the position of the subject (it) which is after the finite (does).

\section{Imperative Mood}

Data : Let us buy American and hire American

\begin{tabular}{|c|c|c|c|c|c|}
\hline Let & Us & \multicolumn{2}{|c|}{ Buy } & American & and hire American \\
\hline & Subject & finite & Predicator & Complement & Adjunct \\
\hline & MOOD: & tive & & RESIDUF & \\
\hline
\end{tabular}

Data : Let's create jobs in America.

\begin{tabular}{|c|c|c|c|c|c|}
\hline Let & Us & \multicolumn{2}{|c|}{ Create } & Jobs & in America \\
\hline Adjunct & Subject & Finite & Predicator & Complement & Adjunct \\
\hline & MOOD: & ative & & RESIDUE & \\
\hline
\end{tabular}

Data : Let us imagine new industries

\begin{tabular}{|c|c|c|c|c|}
\hline Let & Us & Imagir & & new industries \\
\hline Adjunct & Subject & Finite & Predicator & Complement \\
\hline & \multicolumn{3}{|c|}{ MOOD:Imperative } & RESIDUE \\
\hline
\end{tabular}

Data : Let's build a beautiful future together.

\begin{tabular}{l|lll}
\hline Let & Us & build a beautiful future together \\
\hline Finite & Predicator & Subject/complement & Complement \\
\hline \multicolumn{2}{l}{ MOOD: Imperative } & RESIDUE \\
\hline
\end{tabular}

From the data analysis above, the researcher provide the discussion in form of recapitulation of the data analysis. The recapitulations are shown as below :

Table 1.1The Percentage of Mood Type

\begin{tabular}{lllc}
\hline No & Mood Type & Occurence & Presentage \\
\hline $\mathbf{1}$ & Declarative & $\mathbf{1 8}$ & $\mathbf{6 9 , 2} \%$ \\
\hline $\mathbf{2}$ & Interrogative & 2 & $7,7 \%$ \\
\hline $\mathbf{3}$ & Imperative & 6 & $\mathbf{2 3 , 1} \%$ \\
\hline Total & 26 & 100 \\
\hline
\end{tabular}

\section{Speech functions}

In the text of President Donal J.Trump statement found speech functions which give information and solication. In which functions to provide the information and invite Americans to bulid economy American.

\section{Statement (to give information)}


i.e data: I was to share the good news for the American auto Industry.

\begin{tabular}{|c|c|c|c|c|c|}
\hline I & \multicolumn{2}{|l|}{ was } & There & to share the good news & $\begin{array}{l}\text { for the American auto } \\
\text { industry }\end{array}$ \\
\hline Subject & Finite & To be & Adjunct & Adjunct & Complement \\
\hline \multicolumn{3}{|c|}{ MOOD: Indicative (Declarative) } & & RESIDUE & \\
\hline
\end{tabular}

The clause above is declarative clause so the clause is a statement. The clause gives information about the desicion of the good news for the American auto Industry .

\section{Question (to ask for information)}

Data : Does it sound familiar?

\begin{tabular}{llll}
\hline Does & It & Sound & Familiar \\
\hline Finite & Subject & Predicator & Complement \\
\hline & MOOD: Interrogative & RESIDUE \\
\hline
\end{tabular}

The clause above is interrogative clause so the clause is a question. The clause asks the information about American's opinion but in the case the question did not have a answer. The speaker think that when he fought to defend the forgotten men and women from the arrogant elite of his day, then the speaker ask to the listeners whether the listeners agree or not with the opinion.

From the data analysis above, the researcher provide the discussion in form of recapitulation of the data analysis. The recapitulations are shown as below :

Table 1.2The Percentage of Speech Functions

\begin{tabular}{llcc}
\hline No & Mood Type & Occurence & Percentage \\
\hline 1 & Statment (to give information) & 3 & $75 \%$ \\
\hline 2 & Question (to ask for information) & 1 & $25 \%$ \\
\hline Total & 4 & 100 \\
\hline
\end{tabular}

\section{CONCLUSION}

The Systemic Functional Grammar (SFG) offers a view of the purpose language meaning. Which, the meaning refer to our regarding a interepersonal or proposition. The representation of our experiences or experiental (consciousness) and the relevance of the organizations in the sorrounding context (textual). The choice of each dimensions within a system, in which the meaning is realised of potential stuctures variety. The development of language to the cater new meanings that need the representation in communication. The analysis of sytemic functional grammar in the statment by Donal J. Trumps can help the listeners or reader to get the interpersonal meaning of him statement. 
From the result and disscussion above of interpersonal meaning and the speech functions found in the statement of President Donal J.Trump Remaks in weekly address. The writers concludes that frist, by analzying the type of mood which finds that the declarative mood is mostly used in the statement, it reveals the relationship between the speaker and listeners or readers. The speaker as the interlocutor is the provider the information and the listeners is the recepient of the information. Analyzing the modality which finds the mood and finite is less used in the text yahn finite tense. The analysis in this reasearch has found the statment mostly appears in the text wheras question only appears once which indicate that the main function of the statment to give the information.

\section{ACKNOWLEDGMENTS}

In the name of Allah, The Beneficent, The Merciful. All praised be to Allah, Lord of the world, who has given the author His blessing, compassion, and strength to finish this paper. Without the strength, which was given by Allah, this task would never finish. Peace and salutation be upon to the prophet Muhammad, his family, his companions, and his followers.

In this occasion, authors would like to express gratitude to honorable Kaswan, S.Pd MM. for all the precious and uncountable time, advice, suggestions, comments, motivation, and support during the process of doing this paper.

Next, the author also wants to express her appreciation to the people who helped her to finish this assignment. Therefore, her appreciation goes to:

Dr. H. Heris Hendriana, M.P.d, as the Head of IKIP SILIWANGI.

Dr. Irma Savitri Sadikin, M.Pd., as the Head of English Education Study Program

\section{REFERENCES}

Eggins, S., \& Slade, D. (1997). Analysing casual conversation. Equinox textbooks and surveys in linguistics.

Gerot, L., \& Wignel, P. (1994). Making Sense of Functional Grammar. North, (2).

Halliday, M. A. K., \& Matthiessen, C. M. I. . (2004). An Introduction to Functional Grammar. An Introduction to Functional Grammar, 700. https://doi.org/10.4324/9780203431269

Halliday, M. A. K., \& Matthiessen, C. M. I. M. (2014). Halliday's Introduction to Functional Grammar. https://doi.org/10.4324/9780203431269 